\title{
STRUCTURES IN AN AREA NORTH-EAST OF FISKENÆSSET, WEST GREENLAND
}

\author{
A. M. Hopgood
}

\section{Introduction}

The area under discussion borders the Inland Ice $75 \mathrm{~km}$ north-east of Fiskenæsset and consists of about $250 \mathrm{~km}^{2}$ of predominantly anorthositic gneisses, with streaky biotitic and hornblendic gneisses forming the other major rock unit. Amphibolites and late rectilinear, unmetamorphosed basic dykes are of relatively minor importance, constituting probably less than $5 \%$ of the whole. All these units with the exception of the dolerite dykes are parallel or sub-parallel to one another and are disposed in a series of large, moderately tight folds with axial planes symmetrically related to the lithological banding. These folds in places are isoclinal and their axial traces are gently curved, trending on average south-east (fig. 9). Immediately to the south of the area the trend of the major lithological units swings from south-east to south and then curves to the south-west, an effect ascribed to the influence of folds developed during the third and fourth fold episodes in the deformational sequence which is discussed here.

On a large scale the tight to isoclinal folds refold other, attenuated isoclinal folds considered to belong to the first $\left(F_{1}\right)$ set in the sequence recognised. All the major lithological units have been affected by the $F_{1}$ episode of folding. Curvature of the axial traces of the first and second fold sets is due to a combination of effects arising predominantly from deformation during the fifth, sixth and seventh fold episodes. The effects of these on a large scale have not been distinguished individually, although the reversal of plunge sense in the central part of the area is almost certainly the result of folding on easterly trending $F_{5}$ axial planes.

Perhaps the most striking fact which emerges from the present investigation is the broad similarity between the fold sequence in this area and that determined from an area adjacent to the Frederikshåbs Isblink approximately $50 \mathrm{~km}$ to the south (Hopgood, 1973). The principal distinction between the two sequences is merely a difference in orientation of axial planes of equivalent fold sets, especially the earlier ones.

Fig. 9. Sketch map of the lithology of the area simplified to show major $F_{1}$ and $F_{2}$ folds, reversal of plunge of $F_{1}$ and $F_{2}$ fold axes by east-north-east trending $F_{5}$ folds (centre) and swings in trend probably due to $F_{7}$ warping. The broad curvature (concave to the west) is the beginning of the change in strike resulting from refolding by $\mathrm{F}_{3}$ or $\mathrm{F}_{4}$ folds. 


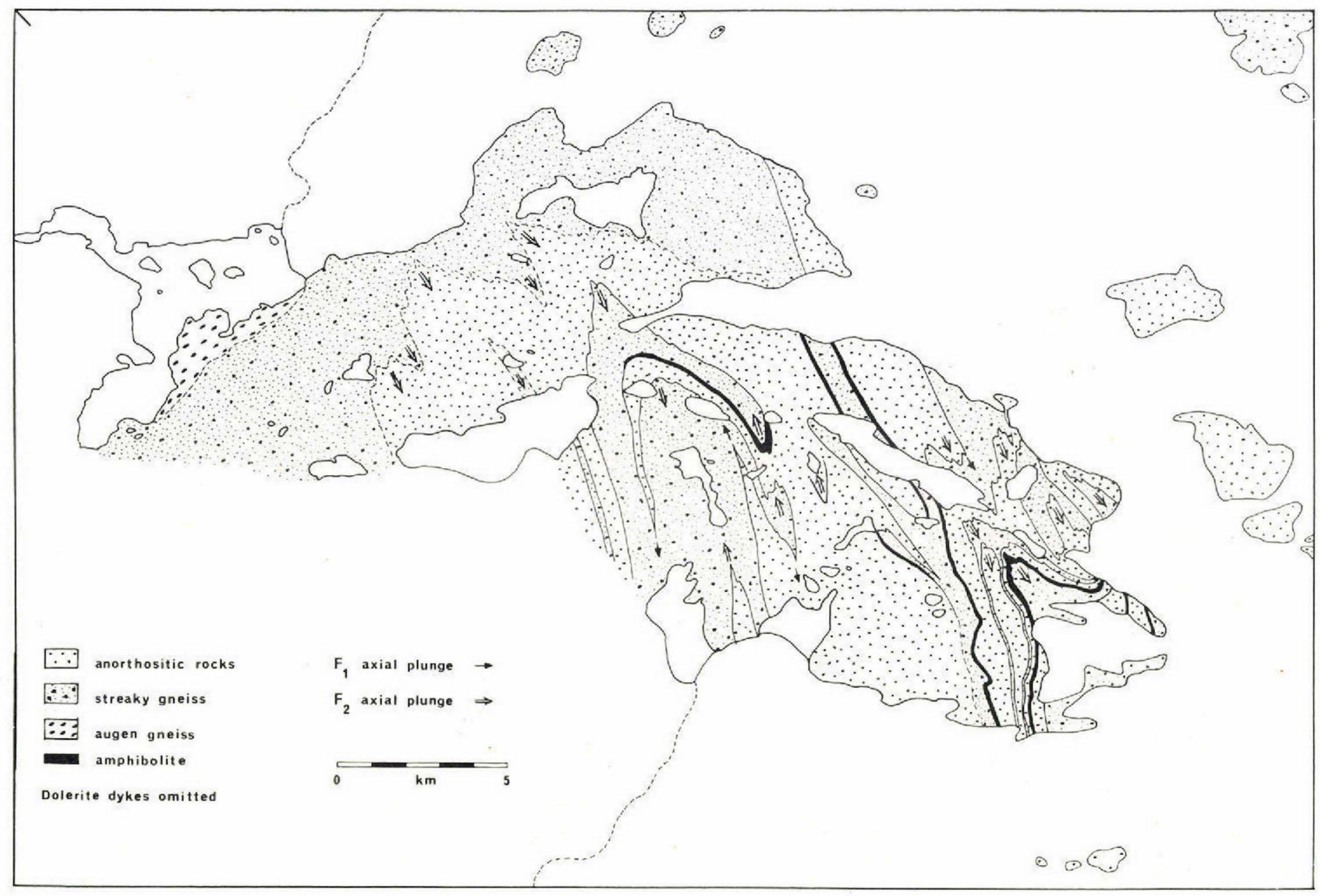




\section{Geological sequence}

In outline the principal events affecting the area are:

Emplacement of the anorthosites and amphibolites (? in existing basement).

Emplacement of parent material of streaky gneisses with formation of white (anorthosite) agmatites.

Folding (isoclinal $F_{1}$ folds) with locally, extreme flattening of feldspar megacrysts.

? Emplacement of further streaky gneiss material with formation of white agmatites containing disorientated flattened feldspar megacrysts.

Emplacement of homogeneous, fine grained, cement grey diorites containing xenoliths of anorthosite.

Development, probably at this time, of augen gneiss (? autochthonous, in part intrusive?).

Folding (tight to isoclinal $\mathbf{F}_{\mathbf{2}}$ folds).

Folding (asymmetrical, inclined to recumbent, $F_{3}$ folds with syntectonic granitic veining and axial planar mineral growth).

Development of parautochthonous grey tonalite bodies containing ghost relicts of $F_{3}$ structures and xenoliths where intrusive.

Folding (inclined asymmetrical $\mathrm{F}_{4}$ folds with syntectonic granitic veins).

Folding (steeply inclined to sub-vertical easterly $F_{5}$ folds with faint axial planar structure).

Folding (open, upright south-easterly $F_{6}$ folds).

Folding (very open, upright north-north-easterly $\mathrm{F}_{7}$ warps with faint axial planar structure).

Emplacement of vertical, northerly rectilinear dolerite dykes.

Faulting with easterly lateral displacement on vertical planes.

Emplacement of vertical, easterly rectilinear dolerite dykes.

\section{Fold sequence}

The largest folds recognised within the area are those formed during the first and second fold episodes and only small scale examples of subsequent generations have been seen.

In general, stress conditions throughout most of the deformational history appear to have been such that movement was predominantly in response to horizontal compression and this produced folds which were initiated mainly by flexure. These were modified subsequently in response to shear and flattening. At times syntectonic metamorphism, at least locally, caused the growth of minerals with preferred orientation parallel to fold axial planes, particularly in the case of the first and third generations.

First and second folds. The stress distribution and orientation during the first fold episodes cannot now be determined because all such folds are isoclinal and have subseqently been highly deformed and conseqently strongly reorientated.

Third folds. By the time of the third episode of folding there is good evidence for the nature of the external stress field. The folds of this generation are invariably asymmetrical with axial planes inclined at significant angles to the mean foliation attitude, and nearly always gently dipping or recumbent, thus implying that they formed in response to the action of a stress couple inclined at a low angle to the horizontal. But for the fact that conditions which existed at the crustal levels now exposed favoured migmatisation and generation of quartzo-feldspathic material in situ, this deformation phase would probably have found expression in low angle thrusting. In fact it is usual to find folds with one limb replaced by shear surfaces taking up movement which sometimes amounted to several centimetres. This movement was almost invariably accompanied by the generation in situ of parallel quartzo-feldspathic vein material. 
In a few extreme cases $F_{3}$ folds appear to have developed entirely by simple shear and they then tend to be isoclinal with axial planes, limbs and quartzo-feldspathic veins all more or less parallel to the direction of shear. On the other hand, the larger $F_{3}$ folds tend to have sheared-out limbs and may lack the usual association of quartzo-feldspathic veining, but it is rare to find them without axial planar mineral growth. Very large scale folding belonging to this generation may have been the cause of reorientation of the large scale, second generation folds resulting in the marked swing in foliation trend immediately to the south of the area.

Fourth folds. Fourth generation folds are also asymmetrical but have slightly steeper axial planes inclined in a generally westerly direction. The smaller and more angular folds may have one limb offset or replaced by a dislocation surface, itself marked by a thin quartzo-feldspathic vein continuous with quartzo-feldspathic veining parallel to the foliation. This effect is similar to that shown by $F_{3}$ folds both here and in the Frederikshåbs Isblink area (Hopgood, 1973).

From the foregoing it is clear that the smaller $F_{4}$ folds at least were not therefore developed entirely by simple flexure but arose in part because the simple shear responsible for them has been restricted to discrete surfaces rather than being distributed throughout the rock in a penetrative fashion. Under more brittle conditions these surfaces would have been simple faults offsetting the foliation. But instead, conditions were such that incipient shear was enough to initiate the generation in situ of the quartzo-feldspathic pegmatitic material which appears to have been contemporaneous with that parallel to the folation. This aspect of fourth generation folds was not recognised in the Frederikshasbs Isblink area (Hopgood, 1973).

It seems that the $\mathrm{F}_{4}$ 'shear folds' formed at a late stage in the flexural folding or immediately after those folds which were generated primarily by flexure, because the axial planes of the flexural folds are essentially parallel to the pegmatite shears. Furthermore it seems that conditions at this level had either remained migmatitic since the $F_{3}$ fold episode, or that there was a return to migmatitic conditions with the onset of $\mathrm{F}_{4}$ folding. The rotational effect of the shear accompanying $\mathrm{F}_{4}$ folding can often be seen to have caused reorientation of $\mathrm{F}_{3}$ axial planes.

Larger scale $F_{4}$ folds appear to be predominantly flexural in origin as was found to be the case in the Frederikshåbs Isblink area.

Fifth folds. Approximately east-trending upright folds represent the fifth fold generation. On clean exposures of the foliation a fine sub - vertical planar structure strikes parallel to this axial planar direction and appears to be comparable to the fine fracture cleavage seen in the autochthonous tonalites and granodiorites of the Frederikshåbs Isblink area (Hopgood, 1973).

Sixth and seventh folds. Few indications have been seen of sixth generation folds which in the Frederikshåbs Isblink area have more or less south-east trending upright axial planes. Their apparent rarity in the present area is attributed to the fact that here (unlike the southern area) $F_{2}$ folds trend south-east and in many cases their axial planes are steeply inclined, so that superimposed upright open folds of comparable orientation would be visible only on outcrops displaying favourably orientated foliation e.g. those in which $F_{2}$ axial planes are gently dipping or where the foliation is sub-horizontal in the hinge zones of $F_{2}$ folids. Rarely $F_{6}$ folds can also be seen affecting recumbent $F_{3}$ axial planes.

The latest set of folds observed are very open warps on vertical axial planes striking 
east of north. Parallel to this direction there is visible on fresh exposures of micaceous foliation a very fine planar structure comparable to that which lies parallel to $F_{5}$ axial planes.

\section{Discussion}

The relationship between the various fold sets in this, and the Frederikshåbs Isblink areas, in particular their geometry and orientation, provides a number of clues to the nature of the early Precambrian crust and its structural evolution in the Fiskenæsset region.

The regularity of orientation of the third and fourth sets of fold structures implies that after they were formed the structural pattern in the Fiskenæsset region had already begun to stabilize in its present form. Thus at the close of the fourth fold episode, not only was there a shift away from migmatitic conditions in the crust at this level, but there appears also to have been a reduction in tectonic activity so that there was no further major structural reorientation of the crustal fabric after that time. Deformation was confined to smaller scale buckling and warping on upright axial planes and this probably tended to increase crustal rigidity, without significantly changing the dominant large scale structural pattern. This hypothesis is of course subject to confirmation or modification in the light of further investigation of large and small scale structures in the intervening areas of the Fiskenæsset region.

Another aspect of the Fiskenæsset deformational sequence which may well be significant is the indication that most of the structures were formed in response to the action of stress which was directed sub-horizontally. Stress couples of this orientation must have been responsible for the third and fourth generation asymmetrical, inclined folds and the later, fifth, sixth and seventh upright open folds and warps must have resulted from compression in a dominantly horizontal tectonic regime of a type which may well have been in existence for more than $3000 \mathrm{~m} . \mathrm{y}$. (Pidgeon, 1973).

The common association with the folding of autochthonous quartzo-feldspathic veins and the presence of autochthonous tonalites and granodiorite bodies and dykes shows that the area now exposed was, throughout the early part of its deformational history, subjected to conditions favouring migmatite formation. This in turn suggests that unless the thermal gradient was very high, deformation took place at relatively deep crustal levels. A high thermal gradient, or at least a regime of comparatively high heat flow is generally believed to have existed at this time. This condition does not, however, appear to have significantly affected the ability of the gneisses and migmatites to transmit stress over wide areas to produce fold patterns with consistent orientations.

It can be said with reasonable certainty that the tectonic processes operating at this level during the early crustal history of this region appear to have produced a deformational pattern which does not differ substantially in its fundamental features from those recognised in the later Precambrian (Hopgood \& Bowes, 1972), and in rocks affected by post-Cambrian orogenic episodes such as the Caledonian. In all of these it is possible to recognise distinctive fold sequences in which patterns of cross folding have been developed which show consistent orientation of fold sets in the later episodes. This strongly suggests deformation in response to stresses whose directions were consistent over considerable distances. That similar deformational sequences could have been produced in more than one way, by dissimilar mechanisms, is considered to be rather unlikely and it seems therefore that at least some crustal processes in the Archaean were comparable to those operating during more recent orogenic episodes. 


\section{References}

Hopgood, A. M. 1973: The pre-Ketilidian history of the gneisses north-west of Frederikshåbs Isblink, Fiskenæsset region. Rapp. Grønlands geol. Unders. 51, 54-59.

Hopgood, A. M. \& Bowes, D. R. 1972: Correlation by structural sequence in Precambrian gneisses of north-western British Isles. Rep. 24th int. geol. Congr. Canada, 1972, 1, 195-200.

Pidgeon, R. T. 1973: Discordant U-Pb isotopic systems in zircons from a granite north-west of Frederikshåbs Isblink, Fiskenæsset region. Rapp. Grønlands geol. Unders. 51, 28-30. 